bryg. dr inż. Jacek Zboina ${ }^{1}$

mgr inż. Michał Chmiel ${ }^{1}$

Maria Kędzierska ${ }^{1}$

mgr inż. Marta Gołaszewska ${ }^{1}$

Przyjęty/Accepted/Принята: 02.02.2015;

Zrecenzowany/Reviewed/Рецензирована: 16.03.2015;

Opublikowany/Published/Опубликована: 31.03.2015;

\title{
System wsparcia odbiorów i testowania wyrobów oraz rozwiązań na rzecz ochrony przeciwpożarowej ${ }^{2}$
}

\author{
Support System for the Acquisition and Testing of Products and Solutions Concerned \\ with Fire Protection
}

\section{Система поддержи приёма и тестирования изделий, а также решений для пожарной охраны}

\begin{abstract}
A B S T R A K T
Cel: Celem artykułu jest przedstawienie wdrożonego, funkcjonującego i stale doskonalonego „Systemu wsparcia odbiorów i testowania wyrobów i rozwiązań stosowanych w ochronie przeciwpożarowej”. Opisano idee, przyjęte kierunki, a także cele postawione przed tym systemem. Wdrożenie to jest rozwiązaniem zidentyfikowanych problemów i potrzeb w aspekcie szkolenia oraz doskonalenia zawodowego personelu, a także inspirowania innowacyjności w ramach testowania wyrobów i rozwiązań innowacyjnych. W artykule ograniczono przedstawienie tego rozwiązania głównie do podsystemu wsparcia odbiorów, drugi podsystem testowania będzie przedmiotem odrębnej publikacji.

Wprowadzenie: Wyroby i system ich dopuszczania to ważne elementy ochrony przeciwpożarowej. Świadectwa dopuszczenia CNBOP-PIB w powiązaniu z certyfikacją wyrobów budowlanych stosowanych w ochronie przeciwpożarowej stanowią podstawę dla zapewnienia bezpieczeństwa pożarowego i prowadzenia działań ratowniczo-gaśniczych. W obszarze stosowania tych wyrobów istnieją określone potrzeby definiowane zarówno przez Państwową Straż Pożarną, jak i środowisko producentów oraz ich dostawców. Odpowiedzią na te potrzeby jest opracowany, wdrożony i doskonalony „System wsparcia odbiorów i testowania wyrobów i rozwiązań stosowanych w ochronie przeciwpożarowej”.

Metodologia: W pracy przedstawione zostały wyniki analizy literatury przedmiotu, badań, doświadczeń i prac własnych autorów publikacji, a przede wszystkim wniosków i doświadczeń wynikających z udziału w tworzeniu i doskonaleniu tego systemu.

Wnioski:

- Jest to nowe i innowacyjne rozwiązanie (system), które kompleksowo łączy elementy (działania) z dwóch głównych obszarów - wsparcia odbiorów sprzętu i wyposażenia wprowadzonego do użytkowania w jednostkach ratowniczo-gaśniczych PSP oraz testowania nowych i innowacyjnych wyrobów i rozwiązań, które można zastosować na potrzeby ochrony przeciwpożarowej.

- System ten w zakresie wsparcia odbiorów stanowi pionierski program edukacyjny dotyczący szkolenia, doskonalenia zawodowego i dobrowolnej certyfikacji personelu Państwowej Straży Pożarnej zajmującego się zakupami sprzętu ratowniczo-gaśniczego, zagadnieniami logistyki i kwatermistrzostwa.

- W ramach tego systemu przygotowano i wdrożono procedurę testowania wyrobów innowacyjnych [6]. Przygotowanie i wdrożenie koncepcji funkcjonowania tego podsystemu pozwala aktualnie na nieodpłatne testowanie nowych

1 Centrum Naukowo-Badawcze Ochrony Przeciwpożarowej im. Józefa Tuliszkowskiego Państwowy Instytut Badawczy; Józefów; jzboina@cnbop.pl / Scientific and Research Centre for Fire Protection National Research Institute, Poland;

2 Autorzy wnieśli jednakowy wkład merytoryczny w powstanie artykułu / The authors contributed equally to this article;
\end{abstract}


i innowacyjnych wyrobów, rozwiązań i technologii przez strażaków PSP. Proces ten kończy się wydaniem stosownej opinii/rekomendacji dla wyrobu/rozwiązania.

Słowa kluczowe: system wsparcia, testowanie wyrobów, dobrowolna certyfikacja, edukacja, ochrona przeciwpożarowa Typ artykułu: artykuł przeglądowy

\section{A B S T R ACT}

Purpose: The purpose of this article is to describe an established support system, for acquisition and testing of products and solutions concerned with fire protection, which is exposed to constant improvements. Additionally, the paper advances views, provides a focus and aims, which the system should address. Such accomplishments provide solutions to identified problems and needs in terms of training and professional development of staff as well as inspire innovation within the sphere of testing products and innovative solutions. This article is limited to issues concerned with the acquisition of materials whereas the testing of such products and solutions will be the subject of a separate publication.

Introduction: Production of equipment and an approval system is an important part of the fire protection process. CNBOPPIB, as a certification body for products used in fire protection, provides the basis for ensuring fire safety and conduct of firefighting operations. The scope for the use of such equipment is specified by the Polish State Fire Service (PSFS), manufacturers and equipment suppliers. The needs are satisfied by a suitably developed and implemented mechanism, incorporating continuous improvements in testing and acceptance of products and solutions used in protection from the effects of fire.

Methodology: This article provides an outcome from a literature analysis, research, experience and presents results obtained from work performed by the authors, publications and, in particular, lessons and experience gained from participation in the development and improvement of the system.

\section{Conclusions:}

- It is a new and innovative approach, which comprehensively combines identified elements from two major areas - support for accepted equipment used in PSFS units and testing of new and innovative products, and initiatives, which may be utilised for fire protection needs.

- This approach, concerning acquisition support, provides a pioneering educational programme for training, professional development and voluntary certification by PSFS personnel involved in the acquisition of rescue and firefighting equipment, and questions concerning logistics and quartermaster issues.

- Under the auspices of this system a testing procedure of innovative products and initiatives was developed and implemented. Preparation and implementation of this concept allows for free testing of new products, solutions and technologies by PSFS firefighters. This process culminates with an award of an opinion/recommendation about the product or proposed solution.

Keywords: technical approvals, support system, receipt and testing of products, voluntary certification, programme, education, fire protection

Type of article: review article

\section{АННОТАЦИЯ}

Цель: Целью статьи является представление внедрённой, функционирующей и все время совершенствующейся „Системы поддержи приёма и тестирования изделий, а также решений для пожарной охраны”. Описаны идеи, тенденции, а также цели, поставленные перед этой системой. Система является решением выявленных проблем и потребностей относительно обучения и профессионального совершенствования знаний персонала, а также служит вдохновением для создания инноваций в рамках тестирования изделий и инновационных решений. В статье представлено только решение для поддержки подсистемы приёмов, вторая подсистема тестирования будет предметом отдельной публикации.

Введение: Изделия и система их допуска - это важный элемент пожарной охраны. Свидетельства допуска CNBOP-PIB вместе с сертификацией строительных изделий, используемых в противопожарной защите - это основы для обеспечения пожарной безопасности и проведения спасательно-гасящих работ. В сфере использования этих изделий существуют определённые потребности представляемые как Государственной Пожарной Службой Польши (PSP), так и средой производителей и поставщиков. Ответом на эти потребности является разработанная, внедрённая „Система поддержки приёма и тестирования”, которая постоянно совершенствуется, как для изделий, так и для решений, используемых в пожарной охране.

Методология: В работе были представлены результаты анализа предметной литературы, исследований, опыта и собственных работ Авторов публикации, а прежде всего выводов и опыта, полученных в результате создания и совершения этой системы. 


\section{Выводы:}

- Это новое и инновационное решение (система), которое комплексно объединяет его элементы в двух главных сферах - поддержки приёма оборудования и оснащения, которое включено в оснащение в спасательно-гасящих подразделениях PSP, а также тестирования новых и инновационных изделий и решений, которые могут применяться для целей пожарной охраны.

- Данная система в сфере поддержки приёма является пионерской образовательной программой, касающейся обучения, профессионального совершенствования знаний и добровольной сертификации персонала PSP, занимающегося покупками спасательно-гасящего оборудования, вопросами логистики и оснащения.

- В рамках этой системы подготовлена и внедрена процедура тестирования инновационных изделий [6]. Подготовка и внедрение концепции функционирования этой подсистемы в настоящее время позволяет бесплатно тестировать новые изделия, решения и технологии пожарными PSP. Этот процесс заканчивается выдачей соответствующего заключения /рекомендации для изделия / решения.

Ключевые слова: система поддержки, тестирование изделий, добровольная сертификация, образование, противопожарная защита

Вид статьи: обзорная статья

\section{Wprowadzenie}

Współczesne zagrożenia występujące w otaczającym nas świecie wymagają od poszczególnych służb ratowniczych posługiwania się sprzętem ratowniczo-gaśniczym o określonych cechach, w tym niezawodnych, trwałych, ergonomicznych oraz wysokiej jakości. Wyposażenie i sprzęt wykorzystywane przez jednostki ochrony przeciwpożarowej powinny zapewniać wysoką skuteczność prowadzonych działań, dlatego muszą być sprawne i adekwatne do potrzeb użytkownika końcowego. Na przestrzeni lat dzięki staraniom producentów i wprowadzaniu innowacji stają się coraz bardziej skuteczne, a praca ratowników dzięki temu „bezpieczniejsza” i efektywniejsza.

Użytkownicy przy wyborze sprzętu pożarniczego biorą pod uwagę przede wszystkim cechy takie jak:

- ogólne bezpieczeństwo użytkowania,

- ergonomia,

- niezawodność,

- funkcjonalność.

Aby sprostać wszystkim oczekiwaniom jednostek ochrony przeciwpożarowej, w Polsce wprowadzono system dopuszczeń zgodny z rozporządzeniem MSWiA z dnia 20 czerwca 2007 r. w sprawie wykazu wyrobów służących zapewnieniu bezpieczeństwa publicznego lub ochronie zdrowia i życia oraz mienia, a także zasad wydawania dopuszczenia tych wyrobów do użytkowania (Dz. U. Nr 143, poz. 1002 z późn. zm.). System ten oparty jest na ściśle określonych wymaganiach techniczno-użytkowych, adekwatnych do aktualnych potrzeb jednostek ochrony przeciwpożarowej [1].

Zapewnienie bezpieczeństwa użytkownikowi, jak również prawidłowa eksploatacja sprzętu gaśniczego są odzwierciedleniem wymagań techniczno-użytkowych zawartych w załączniku do ww. rozporządzenia MSWiA, wprowadzonego rozporządzeniem zmieniającym z dnia
27 kwietnia 2010 r. (Dz. U. Nr 85, poz. 553). To właśnie one precyzują najważniejsze wymagania w zakresie bezpieczeństwa, ergonomii, niezawodności i funkcjonalności, aby sprzęt i wyposażenie mogły bezpiecznie służyć ratowanym i ratownikom. Mimo tej regulacji prowadzenie zakupów sprzętu i wyposażenia straży pożarnej, w tym wyrobów i rozwiązań nowych i innowacyjnych, w praktyce stwarza określone problemy.

„System wsparcia odbiorów i testowania wyrobów oraz rozwiązań na rzecz ochrony przeciwpożarowej” składa się z dwóch podsystemów. Są to:

- podsystem wsparcia odbiorów wyrobów wprowadzanych do użytkowania w jednostkach ochrony przeciwpożarowej (sprzętu i wyposażenia straży pożarnej),

- podsystem testowania wyrobów i rozwiązań innowacyjnych mogących znaleźć zastosowanie w ochronie przeciwpożarowej [5].

Został on wdrożony w Państwowej Straży Pożarnej i jest stale doskonalony [4]. System ten w zakresie wsparcia odbiorów stanowi pionierski program edukacyjny dotyczący szkolenia, doskonalenia zawodowego i dobrowolnej certyfikacji personelu Państwowej Straży Pożarnej zajmującego się zakupami sprzętu ratowniczo-gaśniczego, zagadnieniami logistyki i kwatermistrzostwa. Obejmuje on zagadnienia z zakresu odbioru i testowania wyrobów służących zapewnieniu bezpieczeństwa publicznego, ochronie zdrowia i życia oraz mienia, wprowadzanych do użytkowania w jednostkach ochrony przeciwpożarowej oraz wykorzystywanych przez te jednostki do prowadzenia działań ratowniczych. Służy także upowszechnianiu wiedzy z zakresu certyfikacji i dopuszczeń sprzętu oraz wyposażenia jednostek ochrony przeciwpożarowej.

Pomysłodawcą „Systemu wsparcia odbiorów i testowania", który został opracowany i wdrożony przez 
pracowników CNBOP-PIB i KG PSP, jest nadbryg. Marek Kowalski, Zastępca Komendanta Głównego Państwowej Straży Pożarnej. System jest odpowiedzią na zdefiniowane potrzeby w zakresie zakupów sprzętu i wyposażenia prowadzonych przez PSP z jednej strony, a z drugiej jeszcze większym „otwarciem się" PSP na innowacje i nowe rozwiązania, które można wykorzystać przede wszystkim $w$ ratownictwie realizowanym przez PSP, jak również na potrzeby działań prewencyjnych ochrony przeciwpożarowej, a także ochrony ludności. Bardzo istotnym celem tego przedsięwzięcia jest edukacja, doskonalenie zawodowe, upowszechnianie wiedzy dotyczącej podstaw prawnych systemu dopuszczeń, wymagań technicznych, nowych rozwiązań, technologii i trendów.

\section{System wsparcia odbiorów i testowania}

Wdrożony i stale doskonalony „System wsparcia odbiorów i testowania wyrobów i rozwiązań stosowanych w ochronie przeciwpożarowej" stanowi rozwiązanie zidentyfikowanych problemów i potrzeb w aspekcie szkolenia oraz doskonalenia zawodowego personelu, a także inspirowania innowacyjności w ramach testowania wyrobów i rozwiązań innowacyjnych. W artykule ograniczono omówienie tego rozwiązania przede wszystkim do podsystemu wsparcia odbiorów, podsystem testowania będzie przedmiotem odrębnej publikacji.

Jednym z celów tego systemu jest upowszechnianie wiedzy z zakresu certyfikacji i dopuszczeń sprzętu oraz wyposażenia jednostek ochrony przeciwpożarowej, ich podstaw prawnych, wymagań techniczno-użytkowych krajowego systemu dopuszczeń, a także wymiana poglądów oraz doświadczeń teoretyków i praktyków. „System wsparcia odbiorów i testowania wyrobów oraz rozwiązań na rzecz ochrony przeciwpożarowej" to pierwszy system kompleksowo opisujący problematykę organizacji i działań w zakresie odbioru i testowania sprzętu wprowadzonego na wyposażenie jednostek ratowniczo-gaśniczych PSP oraz innych podmiotów ratowniczych i przedsiębiorców.

W ramach systemu powstał program edukacyjny i program dobrowolnej certyfikacji personelu, który oparto na dwóch powiązanych ze sobą podsystemach:

1. Działaniach edukacyjnych zwanych systemem wsparcia przy odbiorach wyrobów.

2. Procedurze testowania wyrobów i rozwiązań innowacyjnych przed ich stosowaniem/wdrożeniem w ochronie przeciwpożarowej [6].

Głównymi elementami podsystemu wsparcia odbiorów są:

- szkolenia stacjonarne, e-learningowe i wyjazdowe,
- szkolenia teoretyczne i praktyczne,

- szkolenia podstawowe, doskonalące,

- certyfikacja i recertyfikacja personelu (w wyniku szkoleń i certyfikacji personelu powstała „sieć" - „baza” przeszkolonych osób o określonych kwalifikacjach i kompetencjach, działających we wszystkich województwach i dodatkowo szkołach PSP),

- miniportal (platforma internetowa zapewniająca certyfikowanemu personelowi dostęp do m.in. zasobów takich jak: baza wiedzy, komunikator, kursy i egzaminy e-learningowe) [4].

Głównymi elementami podsystemu testowania są:

- wdrożenie procedury praktycznego testowania wyrobów i rozwiązań innowacyjnych przez strażaków-ratowników w jednostkach ratowniczo-gaśniczych PSP i udzielanie przez CNBOP-PIB na tej podstawie rekomendacji lub opinii dla tych wyrobów/rozwiązań (baza rekomendacji i opinii jest publikowana na stronie internetowej CNBOP-PIB),

- oparcie procedury testowania na aktywnej współpracy z producentami i dostawcami wyrobów i/ lub rozwiązań innowacyjnych, co daje możliwość określenia, weryfikacji wymagań i oczekiwań użytkownika końcowego (ustalanych indywidualnie w programie testowania),

- powiązanie obu podsystemów - możliwość angażowania do testowania osób przeszkolonych w ramach systemu wsparcia,

- testowaniu poddany może być wyrób/rozwiązanie innowacyjne przed jego zastosowaniem przez Państwową Straż Pożarną i inne jednostki ochrony przeciwpożarowej, przeznaczony w szczególności do prowadzenia działań gaśniczych, poszukiwawczo-ratowniczych, z zakresu ratownictwa drogowego, $\mathrm{z}$ zakresu ratownictwa wodnego, $\mathrm{z}$ zakresu ratownictwa wysokościowego, $\mathrm{z}$ zakresu ratownictwa chemiczno-ekologicznego,

- po zakończeniu testowania, w przypadku pozytywnego wyniku, opracowywany jest dokument opisujacy proces testowania wyrobu, wynik testowania oraz zawierający opinię testujących wyrób.

\section{Działania edukacyjne prowadzone w ramach systemu wsparcia przy odbiorach wyrobów stosowanych w ochronie przeciwpożarowej}

W ramach podsystemu wsparcia odbiorów prowadzone są przez CNBOP-PIB szkolenia stacjonarne, e-learningowe i wyjazdowe. Prowadzone są one m.in. metodami e-learningu i blended learningu, co pozwala na połączenie zalet tradycyjnych form 
kształcenia oraz form elektronicznych, eliminując przy tym wady i słabości charakteryzujące każdą $\mathrm{z}$ tych form stosowaną oddzielnie. Są to szkolenia teoretyczne i praktyczne, zakres ich ogólnie można scharakteryzować jako szkolenia podstawowe - służące certyfikacji, doskonalące - na potrzeby ponownej certyfikacji (recertyfikacji).

Celem prowadzonych szkoleń jest upowszechnianie wiedzy praktycznej i teoretycznej z zakresu dopuszczeń oraz certyfikacji sprzętu i wyposażenia jednostek ochrony przeciwpożarowej. Przedmiotowe szkolenia pozwalają ponadto na wymianę poglądów i doświadczeń między przedstawicielami CNBOP-PIB prowadzącymi zajęcia a uczestniczącymi w szkoleniach przedstawicielami KW PSP i jednostek im podległych, a także szkół PSP w zakresie podstaw prawnych, wymagań techniczno-użytkowych, a także funkcjonowania krajowego systemu dopuszczeń oraz niezależnie certyfikacji wyrobów budowlanych stosowanych w ochronie przeciwpożarowej. Cykl szkoleń obejmuje również dyskusję na temat zawartości SIWZ-ów przygotowywanych na potrzeby postępowań przetargowych w odniesieniu do wyrobów objętych obowiązkiem uzyskania świadectwa dopuszczenia, jak również samej organizacji postępowań przetargowych dotyczących sprzętu i wyposażenia jednostek ochrony przeciwpożarowej. Poniżej (ryc. 1.) przedstawiono liczbę osób (w poszczególnych województwach) dotychczas przeszkolonych w ramach szkoleń stacjonarnych i certyfikowanych.

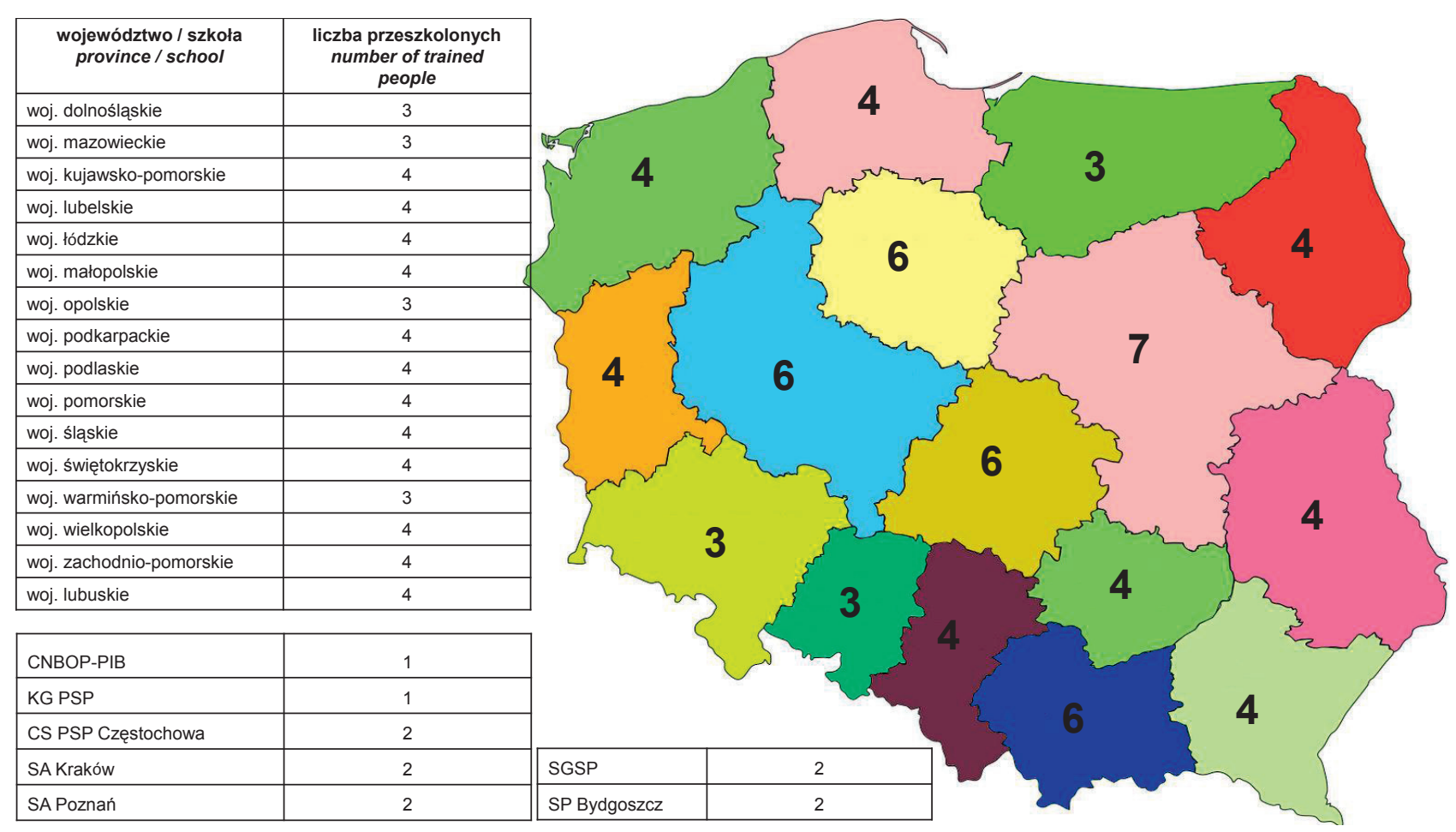

Ryc. 1. Lokalizacja osób certyfikowanych w ramach systemu wsparcia odbiorów w poszczególnych województwach, w tym w szkołach PSP

Źródło: Opracowanie własne.

Fig. 1. Location of certified persons in Poland in the provinces and State Fire Service schools Source: Own elaboration.

Ważną rolę w procesie szkolenia oraz doskonalenia zawodowego i certyfikacji personelu odgrywają szkolenia e-learningowe przeznaczone dla funkcjonariuszy Państwowej Straży Pożarnej zajmujących się zakupami sprzętu ratowniczo-gaśniczego, zagadnieniami logistyki i kwatermistrzostwa, osób certyfikowanych w ramach szkoleń doskonalących, a także dla osób wyrażających zainteresowanie przedmiotową tematyką. Dedykowana, opracowana przez CNBOP-PIB, aplikacja internetowa stanowiąca miniportal wraz z platformą edukacyjną zawiera:
- kursy tematyczne,

- forum aktywności i wymiany poglądów,

- aplikacja jest również bazą wiedzy z tego zakresu, a także zawiera odpowiedzi na najczęściej zadawane pytania.

Miniportal ten zawiera 26 kursów tematycznych. Poszczególne kursy tematyczne przedstawione zostały za pomocą prezentacji multimedialnych, które opisują wybrane zagadnienie. Każdy kurs kończy się testem sprawdzającym. 
Jako pomoc dydaktyczna dla słuchaczy uruchomiona została wyżej wspomniana baza wiedzy. Baza ta zawiera między innymi:

- akty prawne, czyli ustawy i rozporządzenia,

- standardy wydane przez CNBOP-PIB,

- opracowany przez pracowników CNBOP-PIB i KG PSP podręcznik zawierający wszystkie aspekty „Systemu wsparcia” - proces dopuszczenia, wymagania, przepisy prawne, dostępne do pobrania $\mathrm{w}$ formacie PDF,

- forum aktywności, służące do dyskusji lub do informowania uczestników szkolenia o zmianach w procesie nauczania i terminach spotkań,

- FAQ, czyli zbiór najczęściej zadawanych pytań i odpowiedzi na nie, mający na celu udzielenie danemu użytkownikowi pomocy bez konieczności angażowania do tego innych osób, odnoszący się do przedstawionej na platformie tematyki [5].

Szkolenia w zakresie recertyfikacji prowadzone są metodą blended learningu, polegającą na łączeniu zalet tradycyjnych form kształcenia oraz form elektronicznych, przy jednoczesnej eliminacji wad i słabości charakteryzujących każdą z tych form w przypadku stosowania ich oddzielnie. Umożliwia to zmniejszenie kosztów dla organizatora (zakwaterowanie, wyżywienie), jak również dla uczestnika szkolenia przy jednoczesnym poprawieniu ich efektywności (kursant w pewnym zakresie może się uczyć w domu lub w biurze). Blended learning pozwala w sposób wysoce efektywny kształcić i maksymalizować korzyści procesu uczenia się oraz ułatwia realizację przyjętej strategii rozwoju i osiąganie wyznaczonych celów.

Intuicyjność oprogramowania sprawia, że opracowane materiały wspomogą mobilną edukację potencjalnych użytkowników. Na ryc. 2 w syntetyczny sposób przedstawiono główne założenia systemu. Na ryc. 3 i 4 . przedstawiono widok ogólny strony głównej platformy e-learningowej oraz okno logowania. Szkolenie jest dostępne na stronie CNBOP-PIB (Edu. cnbop.pl).

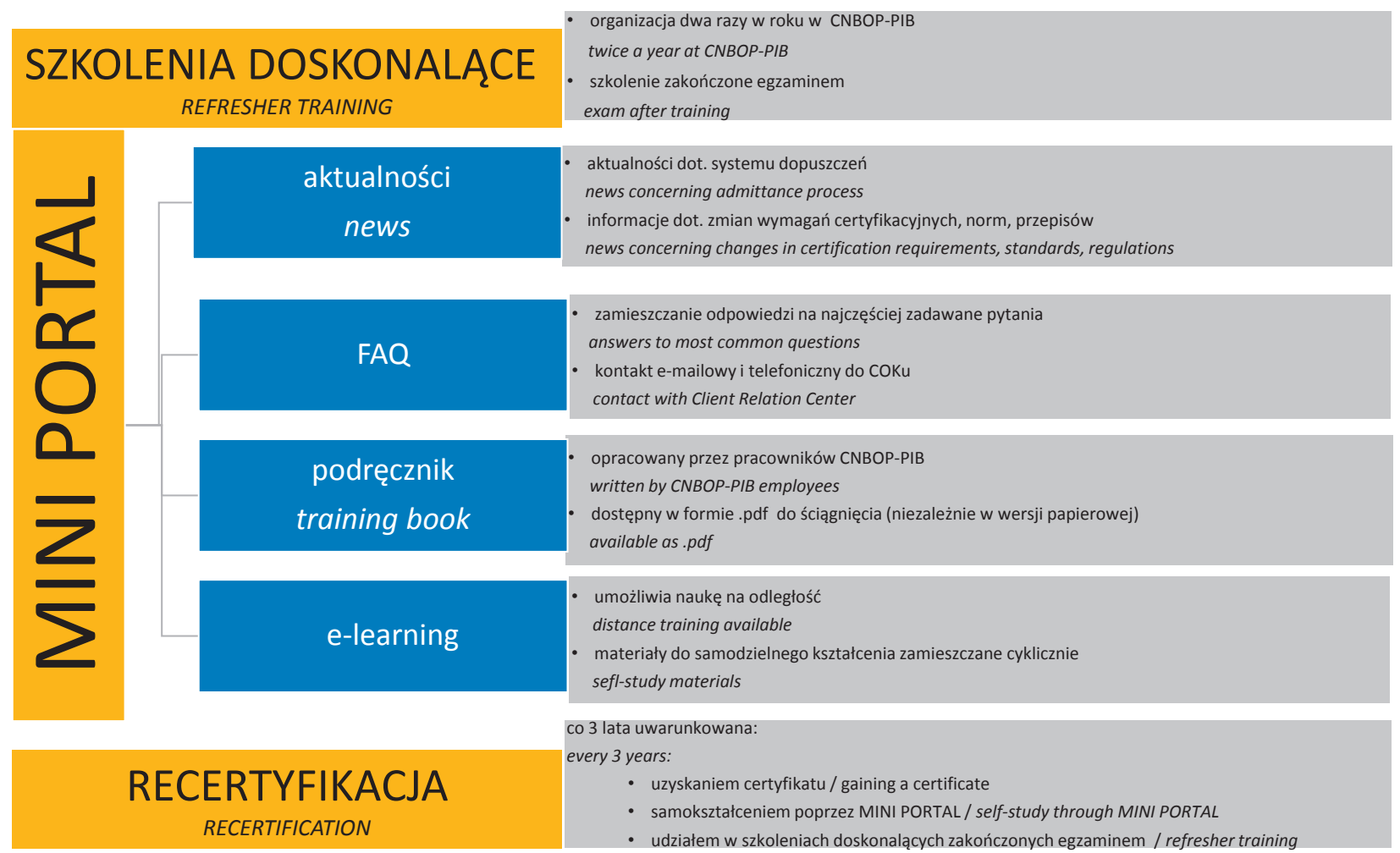

Ryc. 2. Główne elementy w podsystemie wsparcia odbiorów - prezentowane w ramach aplikacji internetowej CNBOP-PIB - miniportal

Fig. 2. Main assumptions of the support system

Źródło: Opracowanie własne.

Source: Own elaboration. 


\begin{tabular}{|c|c|c|}
\hline edu.cnbc & Polski (pl) & *) Zaloguj się \\
\hline & $\begin{array}{l}\text { Platforma edukacyjna CNBOP-PIB } \\
\text { Platforma E-learningowa Centrum Naukowo-Badawczego ochrony Przeciwpożarowej w Józefowie }\end{array}$ & Aplikacja mobilna \\
\hline
\end{tabular}
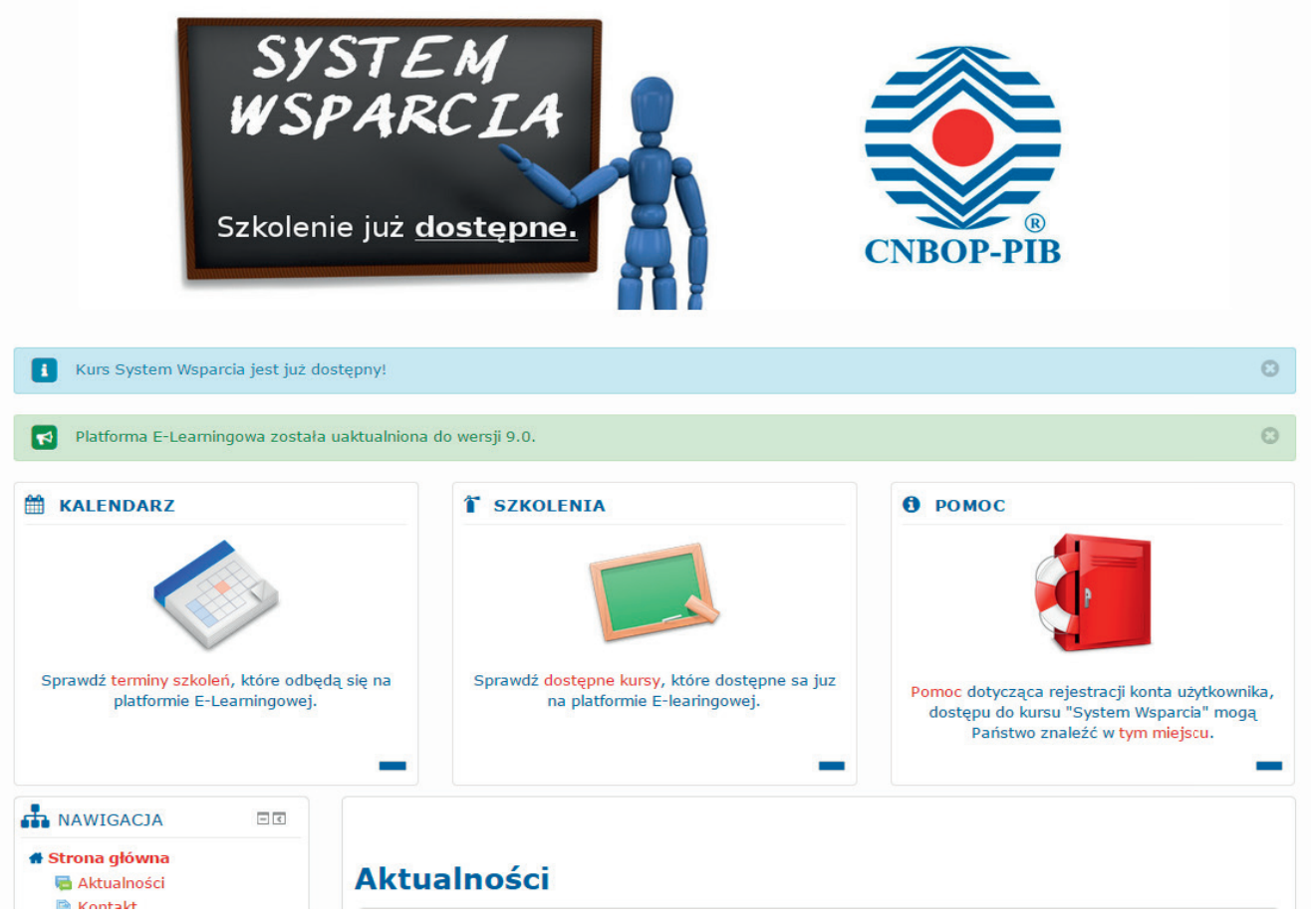

Ryc. 3. Platforma edukacyjna: Edu.cnbop.pl

Fig. 3. Platform Edu.cnbop.pl

Źródło: Opracowanie własne.

Source: Own elaboration.

\section{MINI PORTAL - logowanie}

\section{edu.cnbop.pl $\sim$ Polski (pl)}

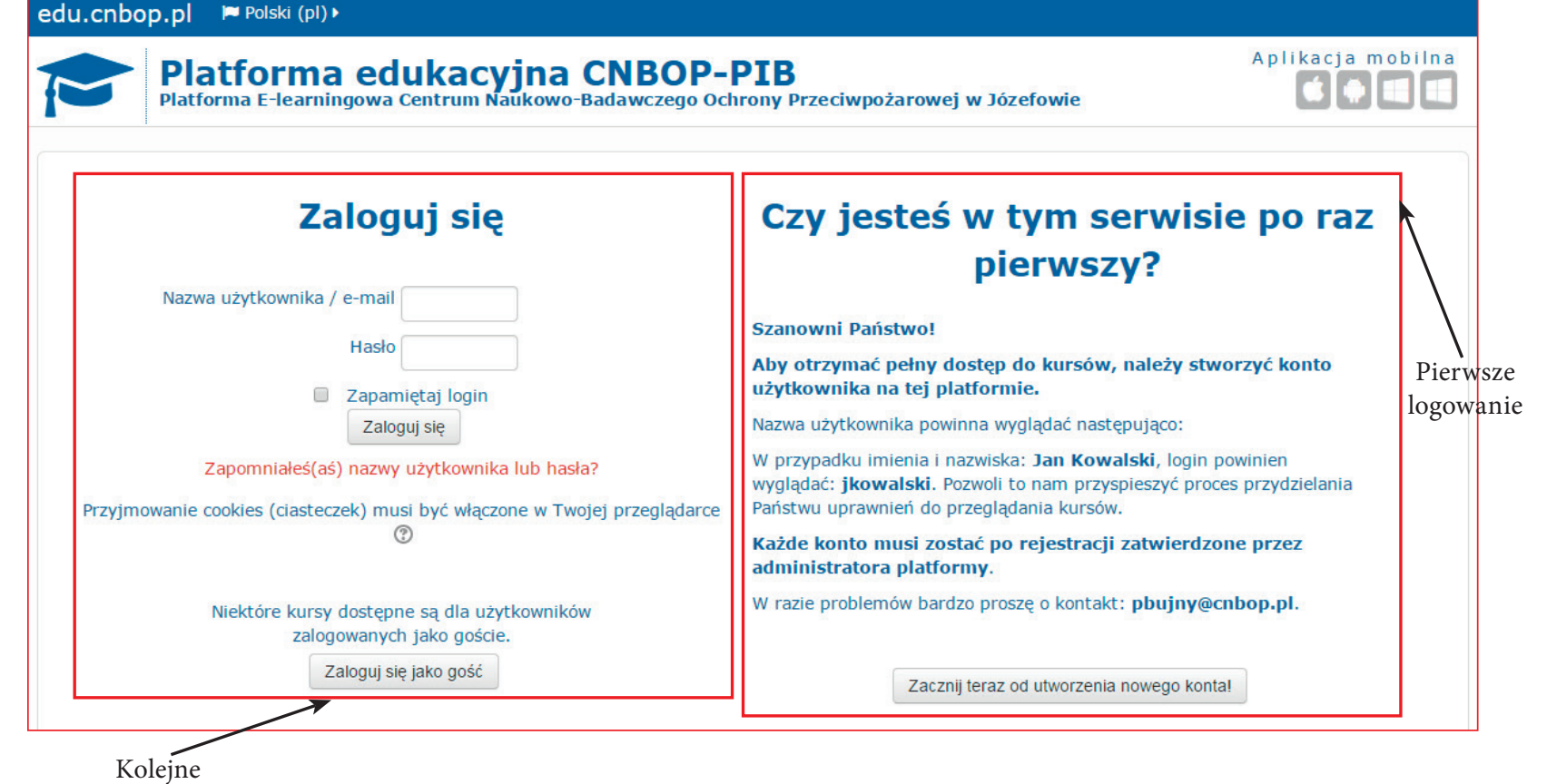

logowanie

Ryc. 4. Ekran - Logowanie

Fig. 4. Login screen

Źródło: Opracowanie własne.

Source: Own elaboration. 


\section{Testowanie wyrobów innowacyjnych}

Drugim ze wspomnianych na początku opracowania podsystemów jest testowanie innowacyjnych wyrobów/rozwiązań przed zastosowaniem ich w ochronie przeciwpożarowej. Wykonywaniem testów wyrobów zajmują się w praktyce strażacy-ratownicy prowadzący na co dzień działania ratownicze z wykorzystaniem wyposażenia i sprzętu. Testowanie odbywa się w wybranych jednostkach ratowniczo-gaśniczych Państwowej Straży Pożarnej zgodnie z indywidualnie ustalanym programem testowania. Oznacza to, że przykładowo sprzęt do ratownictwa wodnego jest testowany przez strażaków pełniących służbę w jednostkach specjalizujących się w ratownictwie wodnym, którzy mają właściwe przygotowanie i doświadczenie $\mathrm{w}$ wykorzystywaniu tego sprzętu do działań ratowniczych. Należy również podkreślić, że testowanie daje możliwość skorzystania ze wsparcia osób przeszkolonych w ramach podsystemu wsparcia przy odbiorach, co pozwala na właściwe weryfikowanie testowanych wyrobów.

Celem wdrożenia podsystemu testowanie wyrobów/rozwiązań innowacyjnych jest:

- wskazywanie potrzeb ochrony przeciwpożarowej poprzez testowanie wyrobów i rozwiązań innowacyjnych przez strażaków,

- inspirowanie poprzez tę współpracę do wprowadzania innowacyjnych rozwiązań przez producentów wyrobów,

- wprowadzenie innowacyjnych wyrobów i rozwiązań do użytkowania w ochronie przeciwpożarowej oraz w przyszłości na rzecz ochrony ludności.

Podczas testowania szczególny nacisk jest kładziony na aspekty ergonomiczne i funkcjonalne oraz rzeczywistą przydatność wyrobów do określonego zastosowania w ochronie przeciwpożarowej. Program testowania jest ustalany indywidualnie dla każdego wyrobu z uwzględnieniem typu i przeznaczenia, jak również właściwości, które są istotne dla producenta oraz użytkownika końcowego.

W wyniku testowania producent zgłaszający wyrób otrzymuje informację zwrotną od użytkowników praktyków o wyrobie, np. dotyczącą jego doskonalenia. Przy założeniu, że testowanie wyrobu odbywa się przed rozpoczęciem produkcji seryjnej wyrobu, producent otrzymuje cenne informacje o wyrobie już na tym etapie. Po zakończeniu testowania, w przypadku pozytywnego wyniku, opracowywany jest dokument opisujący proces testowania wyrobu i wskazujący jego wynik oraz opinię strażaków testujących wyrób [5].

Dla wyrobów nieobjętych obowiązkiem uzyskania dopuszczenia do użytkowania takim dokumentem jest rekomendacja do stosowania w ochronie przeciwpożarowej - udzielana na czas nieokreślony. Rekomendacja stanowi potwierdzenie, że wyrób spełnia oczekiwania użytkownika końcowego i pozwala producentowi na zyskanie przewagi przez jego wyroby. Dla wyrobów objętych obowiązkiem dopuszczenia, ale o właściwościach techniczno-użytkowych istotnie różniących się od określonych w rozporządzeniu MSWiA [2], takim dokumentem jest opinia techniczna. Stanowi ona potwierdzenie, że wyrób spełnia oczekiwania użytkownika końcowego. Po uzyskaniu przez producenta wymaganego dopuszczenia do użytkowania opinia stanowi uzupełniający dokument potwierdzający, że producent wykonał pewne ponadstandardowe działania mające na celu potwierdzenie walorów użytkowych wyrobu, co umożliwia producentowi budowanie jeszcze większego zaufania do jego wyrobów. Współpraca ta prowadzi do powstawania wyrobów bardziej odpowiadających oczekiwaniom ich użytkowników.

Producent ma również prawo do znakowania wyrobu, w okresie ważności OPINII TECHNICZNEJ, znakiem OPINIA TECHNICZNA CNBOP-PIB, który przedstawiono poniżej.

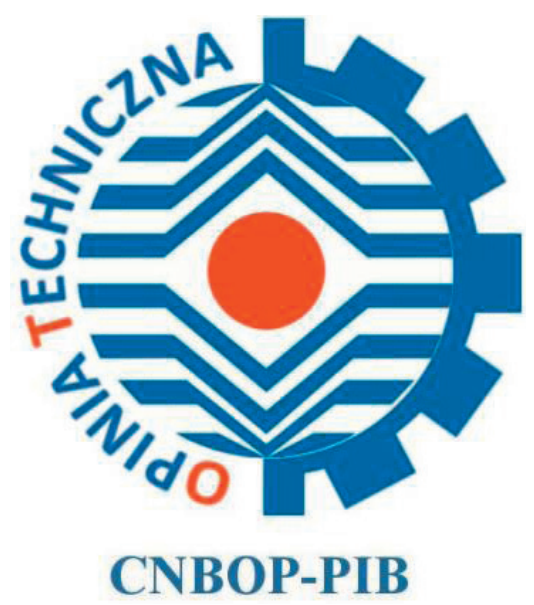

Ryc. 5. Wzór znaku OPINIA TECHNICZNA CNBOP-PIB

Fig. 5. CNBOP-PIB TECHNICAL OPINION mark

Źródło: Opracowanie własne. Source: Own elaboration.

Testowanie wyrobów jest nieodpłatne dzięki wdrożeniu opisanej procedury testowania KG PSP [6] i zaangażowaniu funkcjonariuszy Państwowej Straży Pożarnej. Producent w wyniku jej przeprowadzenia otrzymuje cenne informacje w zakresie kierunków doskonalenia swojego wyrobu.

Efektem końcowym testowania są:

- wyroby (rozwiązania) innowacyjne sprawdzone w praktyce przed wprowadzeniem do użytkowania,

- wyroby doskonalone przez producentów po uwagach użytkowników (strażaków),

- wyroby spełniające wymagania i uwzględniające potrzeby użytkownika, 
- wyroby innowacyjne z REKOMENDACJĄ albo OPINIĄ CNBOP-PIB,

- baza wyrobów posiadających REKOMENDACJĘ/ OPINIĘ na stronie www.

\section{Charakterystyka systemu}

Dokonana analiza pozwoliła na zidentyfikowanie potrzeb, określenie kierunków i celów, które powinny być zrealizowane w obszarze odbioru sprzętu i wyposażenia wprowadzanego na wyposażenie jednostek ratowniczo-gaśniczych PSP i innych jednostek ochrony przeciwpożarowej, co w konsekwencji doprowadziło do opracowania i wdrożenia systemu wsparcia odbiorów i testowania. Analiza ta wykazała, że istnieje potrzeba wprowadzenia rozwiązań systemowych w zakresie wsparcia procedur odbiorowych oraz działań mających na celu wdrażanie w ochronie przeciwpożarowej wyrobów innowacyjnych.

Zakupy sprzętu dla jednostek ochrony przeciwpożarowej wymagają wiedzy formalno-prawnej i specjalistycznej, należytego przeszkolenia, doświadczenia oraz wsparcia zarówno formalnego, jak i technicznego. Opracowany i wdrożony „System wsparcia...” dostarcza osobom przeszkolonym i certyfikowanym istotnych informacji w tym zakresie. Prawidłowe dokonanie odbioru techniczno-jakościowego sprzętu jest ważnym elementem procesu planowania i realizacji zakupów. Wynikająca $\mathrm{z}$ doświadczeń wiedza o występujących podczas odbiorów techniczno-jakościowych sprzętu problemach (błędach, usterkach) prowadzi do wniosku, że konieczne jest nieustanne doskonalenie zawodowe, szkolenie i poprzez te działania poprawa świadomości użytkowników końcowych. Poniżej przedstawione dane statystyczne oparte na reprezentacyjnej grupie wyrobów (środki ochrony indywidualnej, pompy pożarnicze, samochody pożarnicze) wprowadzanych do użytkowania świadczą o skuteczności podjętych działań (systemu wsparcia odbiorów).

W okresie wdrożenia i funkcjonowania systemu w latach 2011-2014 zauważalny jest nawet 30-procentowy wzrost wykrycia błędów w stosunku do lat poprzednich. Powyższe działania w ramach systemu wsparcia odbiorów z pewnością przyczyniły się do znaczącego obniżenia ryzyka odbioru i zakupu sprzętu niespełniającego wymagań prawnych i techniczno-użytkowych. Stanu tego nadal nie można uznać za w pełni zadowalający, dlatego podejmuje się nieustanne działania doskonalące $\mathrm{w}$ celu dostosowania tego systemu do potrzeb.
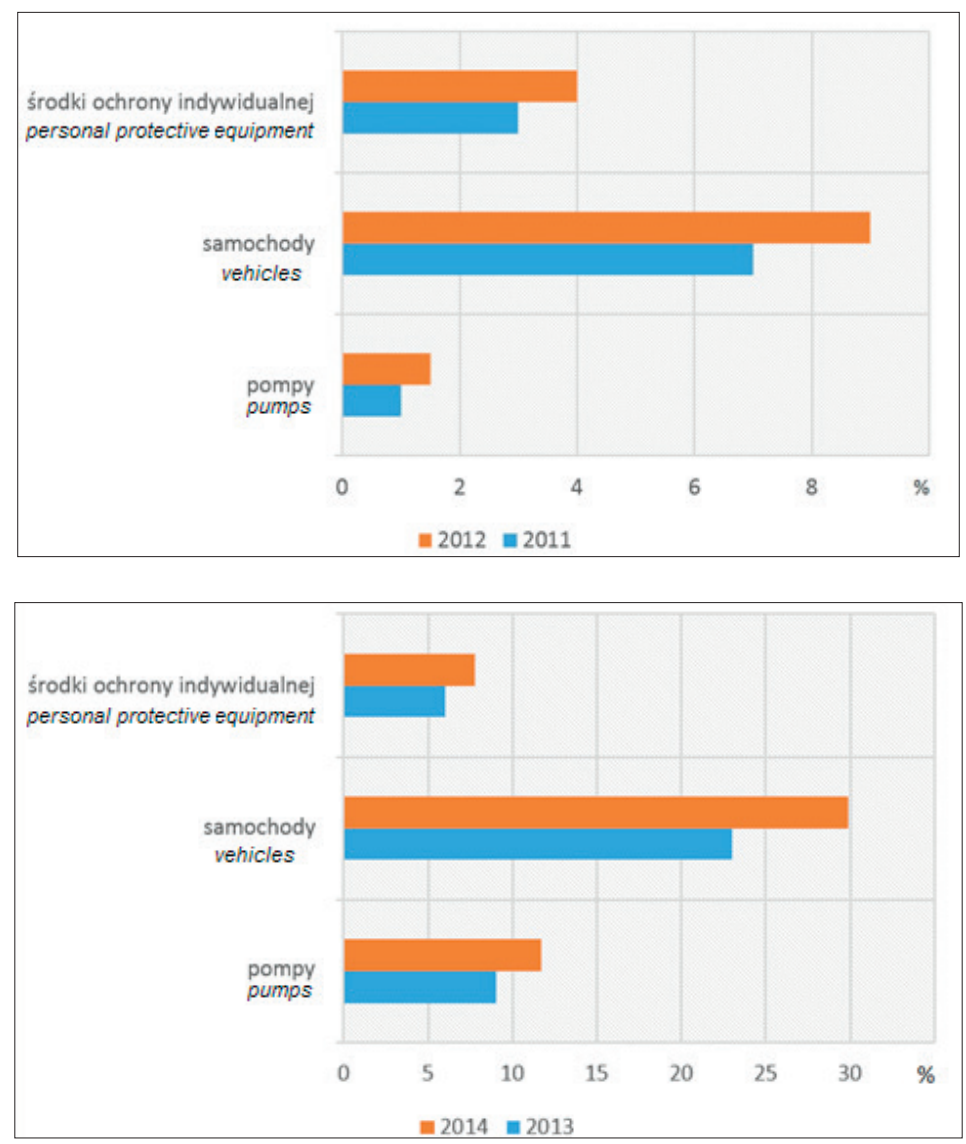

Ryc. 6. Statystyki wykrycia błędów podczas odbioru sprzętu w latach 2011-2014

Fig. 6. Detecting failures during reception of equipment - statistics for years 2011-2014

Źródło: Opracowanie własne.

Source: Own elaboration. 
W celu wsparcia procesu edukacyjnego opracowana została także publikacja zwarta pt. System dopuszczeń i odbiorów techniczno-jakościowych sprzętu wykorzystywanego w jednostkach Państwowej Straży Pożarnej [3]. Publikacja jest efektem współpracy specjalistów z Centrum Naukowo-Badawczego Ochrony Przeciwpożarowej - Państwowego Instytutu Badawczego i Komendy Głównej Państwowej Straży Pożarnej. Wydawnictwo składa się z dwudziestu sześciu rozdziałów. Materiał porządkuje oraz systematyzuje całą procedurę odbioru sprzętu $\mathrm{w}$ ujęciu teoretycznym i praktycznym. Opracowanie to opisuje również przebieg procesu dopuszczenia oraz zawiera wskazówki, jak właściwie czytać świadectwo dopuszczenia. Publikacja opisuje następujące zagadnienia:

1. Proces dopuszczenia wyrobu i wydanie świadectwa dopuszczenia,

2. Pojazdy pożarnicze,

3. Łączniki, nasady, pokrywy nasad, przełączniki, smoki ssawne i rozdzielacze,

4. Prądownice wodne, wodno-pianowe i pianowe oraz wytwornice pianowe

5. Pożarnicze węże tłoczne do pomp pożarniczych, do hydrantów oraz pożarnicze węże ssawne,

6. Aparaty powietrzne butlowe ze sprężonym powietrzem,

7. Maska twarzowa do aparatu oddechowego butlowego,

8. Sygnalizatory bezruchu,

9. Hydrauliczne narzędzia ratownicze,

10. Ubrania specjalne chroniące przed promieniowaniem cieplnym i płomieniem,

11. Ubranie chroniące przed czynnikami chemicznymi,

12. Ubrania specjalne,

13. Pasy strażackie,

14. Linki strażackie ratownicze,

15. Zatrzaśniki strażackie,

16. Skokochrony,

17. Toporek strażacki,

18. Zbiornik przenośny na wodę,

19. Poduszki pneumatyczne do podnoszenia i korki pneumatyczne do uszczelnienia,

20. Drabiny przenośne,

21. Hełmy strażackie,

22. Kominiarki,

23. Buty strażackie,

24. Rękawice specjalne,

25. Motopompy do wody czystej,

26. Motopompy do wody zanieczyszczonej.

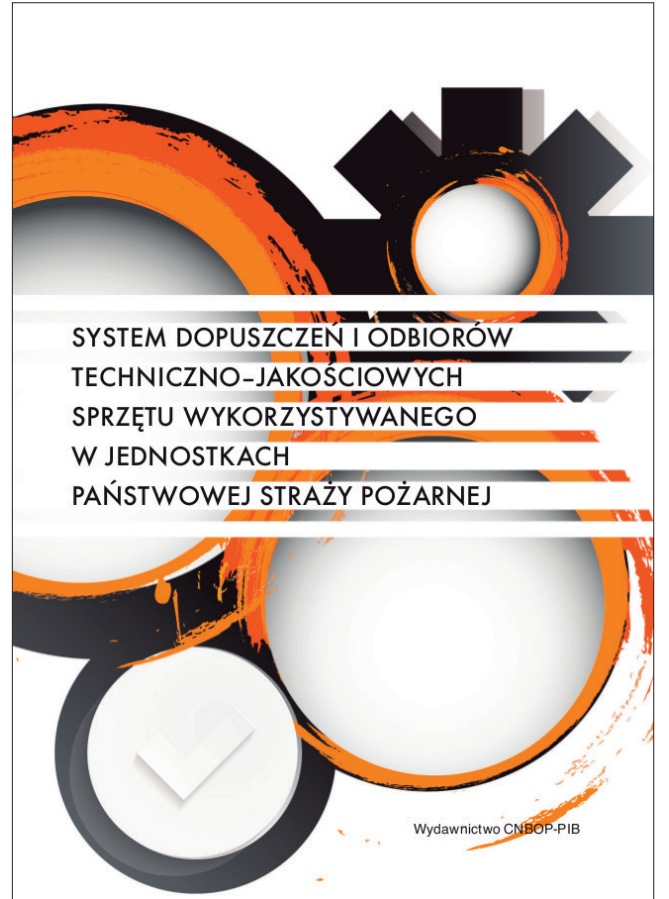

Ryc. 7. Okładka publikacji pt. System dopuszczeń i odbiorów techniczno-jakościowych sprzętu wykorzystywanego w jednostkach PSP

Fig. 7. Cover for a non-serial publication entitled: Acceptance system for technical equipment utilised by the Polish State Fire Service Establishments

Źródło: Archiwum CNBOP-PIB.

Source: CNBOP-PIB archives.

\section{Podsumowanie}

„System wsparcia odbiorów i testowania wyrobów i rozwiązań stosowanych w ochronie przeciwpożarowej" jest to nowe i innowacyjne rozwiązanie, które w sposób kompleksowy łączy w sobie elementy (działania) z dwóch głównych obszarów - wsparcia odbiorów sprzętu i wyposażenia wprowadzonego do użytkowania w jednostkach ratowniczo-gaśniczych PSP oraz testowania nowych i innowacyjnych wyrobów i rozwiązań, które można zastosować na potrzeby ochrony przeciwpożarowej.

System ten w zakresie wsparcia odbiorów stanowi pionierski program edukacyjny mający na celu szkolenie, doskonalenie zawodowe i dobrowolną certyfikację personelu Państwowej Straży Pożarnej zajmującego się zakupami sprzętu ratowniczo-gaśniczego, zagadnieniami logistyki i kwatermistrzostwa.

$\mathrm{W}$ ramach tego systemu przygotowano i wdrożono procedurę testowania wyrobów innowacyjnych [6]. Przygotowanie i wdrożenie koncepcji funkcjonowania tego podsystemu pozwala na nieodpłatne testowanie nowych wyrobów, rozwiązań i technologii przez strażaków PSP. Proces ten kończy się wydaniem stosownej 
opinii/rekomendacji dla wyrobu/rozwiązania. W efekcie wdrożenia i doskonalenia osiągnięte zostały cele stawiane systemowi.

W wyniku wdrożenia tego systemu powstała platforma e-learningowa „System wsparcia...” podzielona na 26 kursów tematycznych i bazę wiedzy z zakresu:

- dopuszczeń oraz certyfikacji sprzętu i wyposażenia jednostek ochrony przeciwpożarowej (podstawy prawne),

- wymagań techniczno-użytkowych,

- funkcjonowania krajowego systemu dopuszczeń,

- certyfikacji wyrobów budowlanych stosowanych w ochronie przeciwpożarowej,

- zasad zakupu sprzętu i najczęściej definiowanych pytań i problemów w tym obszarze.

- Umożliwia ona jednoczesne szkolenie określonej liczby osób (od kilkudziesięciu do kilkuset).

\section{Literatura}

[1] Chmiel M., Przegląd możliwości wykorzystania motopomp do wody zanieczyszczonej $w$ działaniach jednostek ochrony przeciwpożarowej, BiTP Vol. 23 Issue 3, 2011, pp. 77-82.

[2] Rozporządzenie Ministra Spraw Wewnętrznych i Administracji z dnia 20 czerwca 2007 r. w sprawie wykazu wyrobów służących zapewnieniu bezpieczeństwa publicznego lub ochronie zdrowia i życia oraz mienia, a także zasad wydawania dopuszczenia tych wyrobów do użytkowania (Dz. U. Nr 143, poz. 1002), wprowadzonego rozporządzeniem zmieniającym $\mathrm{z}$ dnia 27 kwietnia 2010 r. (Dz. U. Nr 85, poz. 553).

[3] Czerwienko D., Roguski J. (red.), System dopuszczeń $i$ odbiorów techniczno-jakościowych
Edukacja za jej pośrednictwem charakteryzuje się samodzielnością w doborze materiału (osoba uczestnicząca w szkoleniu może zapoznawać się z zagadnieniami objętymi szkoleniem w dowolnej kolejności).

„System wsparcia odbiorów i testowania wyrobów i rozwiązań stosowanych w ochronie przeciwpożarowej" stanowi odpowiedź na zidentyfikowane potrzeby w zakresie zakupów sprzętu i wyposażenia prowadzonych przez PSP z jednej strony, a z drugiej jeszcze większe „otwarcie się" PSP na innowacje i nowe rozwiązania, które można wykorzystać przede wszystkim w ratownictwie realizowanym przez PSP, jak również na potrzeby działań prewencyjnych ochrony przeciwpożarowej i ochrony ludności. Rozwiązanie tych problemów w praktyce zostało przygotowane i wdrożone przez instytut badawczy PSP jakim jest CNBOP-PIB. sprzętu wykorzystywanego w jednostkach PSP, Wydawnictwo CNBOP-PIB, Józefów 2014, ISBN 978-83-61520-06-1.

[4] Zboina J., System wsparcia - recertyfikacja, szkolenia doskonalace, nowe szkolenie personelu, materiały niepublikowane - prezentacja na naradzie Służb Logistycznych i Finansowych Państwowej Straży Pożarnej, Tylna Góra 17-18.11.2015 r.

[5] Zboina J., Testowanie wyrobów innowacyjnych $w$ PSP, materiały niepublikowane - prezentacja na naradzie Służb Logistycznych i Finansowych Państwowej Straży Pożarnej, Tylna Góra 17-18.11.2015 rok.

[6] Procedura testowania wyrobów innowacyjnych, KG PSP wydanie 2 z 12 marca 2015 roku.

bryg. dr inż. Jacek Zboina - pełni służbę w CNBOP-PIB na stanowisku z-cy Dyrektora CNBOP-PIB. Specjalizuje się w ochronie przeciwpożarowej, technicznych systemach zabezpieczeń przeciwpożarowych oraz ocenie zgodności. Absolwent studiów inżynierskich i magisterskich w Szkole Głównej Służby Pożarniczej, ukończył również studia podyplomowe menedżer innowacji w Szkole Głównej Handlowej w Warszawie. Stopień naukowy doktora nauk społecznych w zakresie nauk o bezpieczeństwie uzyskał w Akademii Marynarki Wojennej w Gdyni na Wydziale Dowodzenia i Operacji Morskich. Oficer PSP. Rzeczoznawca Komendanta Głównego PSP ds. zabezpieczeń przeciwpożarowych.

mgr inż. Michał Chmiel - absolwent dziennych studiów I i II stopnia na Wydziale Inżynierii Bezpieczeństwa Pożarowego Szkoły Głównej Służby Pożarniczej. Od 2007 r. pracownik Jednostki Certyfikującej CNBOP-PIB. Aktualnie z-ca kierownika Jednostki Certyfikującej.

Maria Kędzierska - główny specjalista ds. promocji i współpracy CNBOP-PIB. Długoletni pracownik instytutu działający na rzecz upowszechniania wyników badań naukowych i prac rozwojowych oraz edukacji.

mgr inż. Marta Gołaszewska - absolwentka dziennych studiów I i II stopnia na Wydziale Inżynierii Bezpieczeństwa Pożarowego Szkoły Głównej Służby Pożarniczej. Od 2012 r. pracownik Jednostki Certyfikującej CNBOP-PIB. 